\title{
Bir Müzenin Dönüşümü: Öğrence Mekânı Olarak Mardin Müzesi ${ }^{1}$
}

\author{
DOI: $10.26466 /$ opus.816832
}

*

\author{
Nazife Gürhan * \\ * Dr. Öğr. Üyesi, Mardin Artuklu Üniversitesi, Mardin \\ Öz \\ ORCID: 0000-0001-7590-0095
}

Günümüzde müzeler geleneksel olarak kültürel mirasın sergilenmesi ve korunmast işlevlerinin yanı sıra bu mirasın aktarımının daha işlevsel bir sunumuna dair eğitim ve eğlencenin iç içe geçtiği uygulamalar geliştirmeye başlamışlardır. Çă̆daş müzecilik anlayışıyla ortaya çıkan bu uygulamaların amacı müze ziyaretçilerine kültürel miras eğitimi verirken eğlenceli vakit geçirmelerini să̆lamaktır. Ĕ̆itim ve eğlencenin mekânsal olarak kesiştiği bu müzeler bir öğrence mekannna dönüşmüş durumdadır. Bu çalışmada değişen müzecilik anlayışıyla birlikte ortaya çıkan edutainment/öğrence uygulamaları Mardin Müzesi örneğinde ele alınmıştır. Kültürel miras ögelerini bünyesinde barındıran bir mekânın eğitim ve eğlencenin mekânsal olarak kesiştiği bir öğrence mekanına nasıl dönüştüğünü ortaya çıkarmak çalışmanın temel amacıdır. Çalışmada katılımcıların müze deneyimlerinden yola çıkılarak müzeyle olan ilişkileri ortaya konulmaya çalışılmıştır. Bu bağlamda nitel araştırma teknikleri kullanılarak kartopu örnekleme yöntemiyle 3 müze yetkilisi ve 5'i çocuktan oluşan çeşitli yaş gruplarından toplam 15 kişiyle derinlemesine mülakat ve katılıml gözlem yapılmıştır. Çalışmada, edutainment uygulamalarının müze ziyaretçilerinin aktif öğrenme süreçlerine dahil olmasını sağlayarak müzeye olan ilgilerini artırdı ̆̆ heyecanl ve unutulmaz bir müze deneyimi sunduğu görülmüştür. Kültürel kimliğin devamın sağlamanın eğlenceli bir yolu olan atölye çalışmalarıyla yapılan eğitim faaliyetleri müzeyi eğlenerek öğrenilen bir mekâna başka bir deyişle öğrence mekanına dönüştürmüş durumdadır.

Anahtar Kelimeler: Çocuk, müze, mekân, müze ĕ̆itimi, öğrence.

\footnotetext{
${ }^{1}$ Bu makale Mardin Artuklu Üniversitesi Bilimsel Araştırma Projeleri Koordinasyon Birimi tarafından Kabul edilen MAÜ.BAP.18.EF.011 nolu proje kapsamında desteklenmiştir
} 


\title{
A Transformation of a Museum: Mardin Museum as an Edutainment Environment
}

*

\begin{abstract}
Today, museums started to develop practices in which education and entertainment are integrated and cultural heritage transfer is provided more functionally by diverging from the presentation and protection functionalities of cultural heritage. The purpose of these practices that emerged with contemporary museology understanding is to provide entertainment while giving cultural heritage education. In this study, the edutainment practices that emerged with the changing museology understanding were discussed within the Mardin Museum sample. The main aim of the study is to reveal how an environment that includes cultural heritage elements transformed into an edutainment environment. In the study, the relationship of the participants with the museum was determined based on their museum experiences. In this context, in-depth interviews and participatory observation were conducted with a total of 15 individuals from various age groups including 3 museum officers and 5 children with snowball sampling method by using qualitative research techniques. In the study, it was observed that edutainment practices increased the interests of museum visitors to the museum by including them to the active learning processes and presented an exciting and unforgettable museum experience. Educational activities conducted with workshops which is an entertaining way of providing the continuity of cultural identity transformed the museum into an environment in which children learn while having fun, in other words, a student environment.
\end{abstract}

Keywords: children, museum, environment, museum education, edutainment. 


\section{Giriş}

Kültürel mirasın korunmasında önemli bir yer olan müzeler hem kentin kültürel tarihine 1şık tutmakta hem de geçmiş ile günümüz arasında bir köprü görevi görerek yeni nesillere bu mirasın aktarımını sağlamaktadır. Kültürel miras eğitiminde önemli bir role sahip olan müzeler günümüzde geleneksel müzecilik anlayışından uzaklaşarak temel hedef kitlelerinden birisi olan çocuklara yönelik uygulama ve eğitimlerle okul dışı bir öğrenme ortamı oluşturmaktadır. Temelinde öğrenmenin olduğu bu yeni eğlenceli müze ortamında teknolojik gelişmelerin sağladığı avantajlarla oluşturulan dijital ortamlar ve atölye çalışmalarıyla birlikte müzeler ziyaretçiler için bir cazibe merkezi konumuna gelmiş durumdadır.

Mardin Müzesi, 1895 yılında "Süryani Katolik Patrikhanesi" olarak Antakya Patriği İgnatios Behnam Banni tarafından inşa edilmiş ve 2000 yılında Kültür Bakanlığ tarafindan restore edilerek hizmete sunulmuş tarihi bir yapıdır. Mardin evi mimarisinin bütün karakteristik özelliklerini taşıyan müze, tarihi bir mekân olarak öne çıkmaktadır. Müzenin bu fiziki yapısının yanı sıra dikkat çekici özelliklerinden biri de bir yandan Asurlardan Bizans'a, Artuklulardan Osmanlılara kadar Mezopotamya uygarlıklarına ait birçok önemli eseri bünyesinde barındırması diğer yandan da eğitim salonlarındaki sikke basma, kök boya baskı, ebru, seramik yapımı gibi çeşitli atölye çalışmalarıyla ziyaretçilerin -özellikle çocukların- eğlenceli zaman geçirmelerini sağlamasıdır. Ayrıca çocuklara yönelik kış okulu ve yaz okulu etkinliklerinde müze bünyesinde farklı uygulamalar yapılarak çocuklara eğlenceli zaman geçirme imkânı tanınmaktadır.

Çalışmanın ana konusu edutainment uygulamalarının müze yapılanmasında yarattığı dönüşümler ve müzecilik anlayışında ortaya çıkardığı farkl1laşmalardır. Bu bağlamda değişen müzecilik anlayışıyla birlikte ortaya çıkan edutainment/öğrence uygulamalarının Mardin Müzesi'ndeki yansımaları bu çalışmada ele alınmıştır. Kültürel miras ögelerini bünyesinde barındıran bir mekânın eğitim ve eğlencenin mekânsal olarak kesiştiği bir öğrence mekanına nasıl dönüştüğünü ortaya çıkarmak çalışmanın temel amacıdır. Çalışmada katılımcların müze deneyimlerinden yola çıkılarak müzeyle olan ilişkileri ortaya konulmaya çalışılmıştır. Bu bağlamda Mardin Müzesi'ndeki çocuklara yönelik edutainment/öğrence uygulamalarının neler olduğu, bu uy- 
gulamaların çocukların müzeye olan ilişkilerini nasıl etkilediği ve müze yapılanmasında edutainment uygulamalarının etkisinin ne olduğu da çalışmanın cevaplamaya çalıştığı diğer sorulardır.

Literatüre baktığımızda dünyada bu konuda henüz yeni çalışmaların ortaya çıtığ1 görülmektedir. Özellikle müzelerin artık klasik işlevlerinden uzaklaşarak farklılaşması çalışmaların ana temasını oluşturmaktadır. Örneğin Schuster (1998) yaptığı çalışmasında müzelerin hibritleşmesini Amerikan müzelerinden yola çıkarak ele almıştır. Yine Joaquim Rius (2016), çalışmasinda sanat müzelerindeki hibrit modelin yükselişini Barselona örneğinde ele almıştır. Müzelerin değişen doğası (Freedman, 2000), yeniden şekillenmesi (Cembalest, 2009), müzede oyun faaliyetleri (Beale ve Villeneuve, 2011) diğer yapılan çalışmaların ana temalarını oluşturmaktadır. Edutainment uygulamalarının müzelere olan etkisiyle ilgili Lepouras ve Vassilakis (2004)' in müzedeki edutainment uygulamaları için oyun teknolojilerinin kullanımını ele alan çalışması ve Balloffet, Courvoisier ve Lagier' in (2014) müzelerin eğlence parklarına dönüşümünü edutainment uygulamalarının yarattığ1 risk ve firsatlarıyla birlikte ele alan çalışması bulunmaktadır. Ayrıca Baccarin'in (2017) müzelerde edutainment teknolojisiyle ilgili yaptığı bir tez çalışması da vardır.

Türkiye'de ise müzelerdeki edutainment uygulamalarıyla ilgili çok az çalışmalar yapılmış durumdadır. Müzelerle ilgili çalışmalarda daha çok müze eğitiminin öğrencilerin eğitimine katkısı (Abacı, 1996; Artar, 2010; Öner, Uyar ve Öner, 2019) konusunun ele alındığı görülmektedir. Özellikle sosyal bilgiler dersinde müze ziyaretlerinin kullanılması (Yılmaz ve Şeker, 2011; Kısa, 2012; Meydan ve Akkuş, 2014); Öner, 2015) çalışmaların yoğunlaştığı ana temadır. Değişen müzecilik anlayışı (Atagök, 2003; Karadeniz, Okvuran, Artar ve İlhan, 2015) üzerine de çalışmalar mevcuttur. Edutainment ve müze ilişkisi bağlamında ise Syed Ahmed Jawwad Zaidi'nin (2016) müze mekanlarında kullanıcı deneyimlerini zenginleştirmede bir strateji olarak oyunlaştırmanın kullanılması konusu ele aldığı çalışması bulunmaktadır. Karadeniz Akdoğan, Durmaz, Kimzan ve Acer (2019) ise yaptıkları çalışmada bir öğrenme ortamı olarak müze atölyelerini ele almışlardır. Yine bu konuda Yum'un (2020) müze mekanının tasarımında edutainment uygulamalarını ele aldığı bir tez çalışması mevcuttur.

$\mathrm{Bu}$ çalışma ise son yıllarda ortaya çıkan edutainment uygulamalarının hem mekânsal olarak müzeyi nasıl dönüştürdüğünü hem de müze ziyaretçileri açısından müze algısında nasıl bir değişime neden olduğunu sosyolojik 
açıdan ele almasıyla diğer çalışmalardan ayrılmaktadır. Ayrıca Türkiye'de müzelere ilişkin sosyolojik çalışmaların azlığı göz önünde bulundurulduğunda çalışmanın önemi daha da artmaktadır.

\section{Yöntem}

Çalışmada araştırma deseni olarak nitel araştırma yöntemlerinden durum çalışması kullanılmıştır. Chmiliar'a (2010) göre durum çalışması sınırlı bir sistemin nasıl işlediği hakkında sistematik bir şekilde bilgi toplamak amacıyla çoklu veri toplanması ve o sistemin derinlemesine incelenmesidir. Benzer şekilde Creswell (2007) de durum çalışmasını araştırmacının zaman içerisinde sınırlandırılmış bir durumu gözlem, görüşme, görsel işitsel dokümanlar vs. gibi çoklu kaynakları içeren veri toplama araçlarıly derinlemesine incelendiği nitel bir araştırma yaklaşımı olarak tanımlamaktadır (Subaşı ve Okumuş, 2017, s420). Çalışmada veri toplama süreci için yarı yapılandırılmış derinlemesine görüşmeler yapılmıştır. Bu bağlamda 3 müze yetkilisiyle ve müzedeki atölye çalışmalarına katılan yaşları 11 ile 50 arasında değişen çeşitli yaş gruplarından 15 olmak üzere toplamda 18 kişiyle derinlemesine görüşme yapılmıştır. Görüşmeler müze atölyesini kullanan katılımcılar arasından rastgele örnekleme yöntemiyle yapılmıştır. Ayrıca katılımlı gözlem yapılarak da veri elde edilmeye çalışılmıştır. Çalışmanın yapılabilmesi için Mardin Artuklu Üniversitesi Bilimsel Araştırma ve Yayın Etiği Kurulu tarafından 22.07.2020 tarihli ve 2020/ 6-6 sayılı kararı ile gerekli izin alınmıştır. Veri toplama sürecinde gözlem ve görüşmeler sonucunda elde edilen veriler bilgisayar ortamına aktarılmıştır. Veriler analiz edilirken de betimsel analiz yapılmıştır. Yıldırım ve Şimşek'e (2013, s.256) göre betimsel analiz yaklaşımına göre elde edilen veriler daha önceden literatürden elde edilen temalara göre yorumlanmaktadır. Bu bağlamda çalısmada belirlenen tema ve kodlara göre betimsel analiz gerçekleştirilmiştir. Çalışma kapsamında kullanılan bir diğer yöntem ise doküman analizidir. Bu bağlamda müzeye ait web sayfası incelenmiş, tanıtım yazılarından hareketle söylemsel düzeyde kendilerini nasıl kurguladıkları ortaya çıkarılmaya çalışılmıştır.

\section{Edutainment/Öğrence Kavramı}

Eğitime destek olarak ortaya çıan bir kavram olan öğrence (edutainment), esasen eğitim (education) ve eğlencenin (entertainment) birleşimidir. Türkçe 
karşılı̆̆ çoğu zaman öğrence olarak çevrilmesine rağmen Yum (2020) bu kavramı "eğitlence" olarak kullanmaktadır. 1970'lerde ortaya çıkan öğrence kavramı Amerikan Ulusal Coğrafya Akademik Birliği'nden Robert Heyman tarafından "eğlenerek eğitim" olarak adlandırılmıştır (Aksakal, 2015, s. 1232). Öğrence kavramı geleneksel olarak çocukların oyun yoluyla öğrenmelerine yardımcı olmak için tasarlanmış eğitici video oyunlarıyla ortaya çıkmıştır (Feenstra ve diğerleri, 2015, s. 48).

Edutainment/öğrence kavramının çocukların gelişiminde önemli bir yere sahip olduğunu belirten Ateşçi ve İslamoğlu (2014, s. 389), kavramın ilk dönemlerde çoğunlukla az gelişmiş ülkelerdeki toplumsal sorunların çözümünde bir araç olarak kullanıldığını belirtmektedir. Ayrıca kitle iletişim araçları üzerinden toplumları bilinçlendirmek amacıyla da kullanılmaktadır. Genellikle çocuklara yönelik hazırlanan programlarda edutainment/öğrence uygulamalarıyla karşılaşılmaktadır. Bunun nedeni ise çocukların eğitimlerini bir deneyimleme süreci içinde gerçekleştirmesini sağlamak ve keyifli bir deneyim sonrasında öğrenme süreçlerindeki verimi artırabilmektir.

Günümüzde bilgisayar tabanlı öğrenme araçları kullanılarak bilginin oyun yoluyla öğrenilmesinin öğrenme süreçleri üzerinde olumlu etkiler yaptığı düşünülmektedir. Dolayısıyla bu uygulamaların öğrenmenin verimini artırmasına paralel olarak çocuklara yönelik eğitim ve eğlencenin iç içe geçtiği faaliyetlere yönelik ilginin de artışına neden olduğunu söylenebilir (Sorathia ve Servidio, 2012, s. 266). Edutainment/öğrence uygulamalarına modern eğitim sisteminin her alanında sıklıkla karşılaşılmaktadır. Özellikle çocuklara soyut kavramların öğretilmesinde ve yabancı dil becerilerinin geliştirilmesinde başvurulan bu yöntem sayesinde bilginin eğlenceli bir şekilde öğrenilmesi sağlanarak geleneksel öğretim yöntemleriyle hemen hemen aynı düzeyde bilgi edinilmesini mümkün olmaktadır (Anikina ve Yakimenko, 2015, s. 476). Dolayısıyla eğlence yoluyla öğrenme olarak ortaya çıkan bu yeni kavramın ana güdüsünün eğlence ve mutluluk olduğunu söylemek mümkündür.

Öğrenicilerin ilgisini çekerek ve duygularını yenileyerek öğrenmenin sürekliliğini sağlayan edutainment/öğrence (Okan, 2003), öğrencilere kendi bilgilerini nasıl kullanmaları ve öğrendiklerini nasıl değerlendirmeleri gerektiğini de öğretmektedir. Böylece öğrenmesi zor bilgiler, öğrenme heyecanı ve coşkusunu artıran bu yeni sistemle birlikte öğrencilerin dikkati çekilerek daha kolay öğrenilmektedir (Aksakal, 2015, s. 1233). 
Edutainment/öğrence faaliyetleri zamanla klasik eğitimin yapıldığı mekân olan sinıftan farklı olarak çocuklar için daha rahat bir ortam olan kafe, eğlence merkezleri, park, müze gibi okul dışı mekanlarda yürütülmeye başlanmıştır. Dolayısıyla bir oyun biçiminde kurgulanan bu mekanlar formel eğitimden informel eğitime geçişi sağlamakta ve melez/hibrit bir tür olarak karşımıza çıkmaktadır (Anikina ve Yakimenko, 2015, s. 476). Yine tüketim mekanlarından biri olan çocuk oyun alanlarının tasarlanmasında da bu uygulamaların dikkate alındığı görülmektedir. Örneğin son yıllarda ortaya çıkan çocuklara yönelik mekânsal bir üretim olan çocuk şehri temalı eğlence merkezleri edutainment/öğrence uygulamalarını da bünyesinde barındırmaktadır. İstanbul'da örnekleri bulunan bu mekanlar (KidZania, KidzMondo ve Minopolis İstanbul) çocuklara gerçek dünyanın bir simülasyonunu sunarak onların eğlenirken öğrenmelerine imkân tanımaktadır (Gürhan, 2018, ss.718-19). Ayrıca edutainment/öğrence uygulamaları tüketimi artırmanın bir aracı olarak da kullanılmaktadır (Feenstra vd., 2015, s. 49; Poris, 2006, s. 14, Ironico, 2012, s. 32). Örneğin bazı mağazalar çocuklara yönelik yaptı̆̆ı edutainment/öğrence faaliyetleriyle çocukları eğlendirmekte ve böylece ailelerin mağazada çok vakit geçirerek daha fazla alışveriş yapmalarını sağlamaktadır. Dolayısıyla edutainment/öğrence uygulamalarının mağazaların satışı artırmak için kullanılan bir strateji olduğu söylenebilir. Benzer şekilde Japonya'daki mağazalarda yapılan öğrence uygulamalarından bahseden Millie (1994, s. 37), özel mağaza aktivitelerinde -matematik turnuvaları ve coğrafya yarışmaları- eğitime yapılan vurgunun ailelerin mağazaya olan sadakatini artırdığını belirtmektedir.

Edutainment/öğrence faaliyetleri o kadar yaygınlaşmıştır ki bugün oyuncak piyasasının temeline yerleşmiş görünmektedir. Öyle ki çocuklar için tasarlanan kendi kendine gelişim ve eğitim vaat eden eğitici oyuncaklar bugün ailelerin çocuklarına alacakları oyuncak tercihinde önemli bir yere sahiptir. Çocuklar için üretilen oyuncak ve malların satışındaki eğitimsel ve gelişimsel değer iddiaları yaygın bir satış stratejisi olarak karşımıza çıkmaktadır (Millie, 1994, s.46).

Görüldüğü gibi edutainment/öğrence faaliyetleri günümüzde sadece eğitimde başvurulan bir yöntem değil, müze, park, eğlence merkezleri gibi okul dışı mekanlarla mağazalar gibi tüketim mekanlarının da önemli bir unsurudur. Hatta özellikle çocuklara yönelik tüketim piyasasının vazgeçilmez bir 
ögesi olduğu söylenebilir. Kısaca eğitim, tüketim, eğlence ve kültürel faaliyetler gibi toplumsal hayatın her alanında edutainment/öğrence uygulamalarıyla karşılaşılmaktadır. Bu çalışmada öğrencenin kültürel faaliyetlerin merkezinde yer alan müzeler -özelde Mardin Müzesi- üzerindeki etkisi ve hem müzenin mekânsal yapısında hem de müzecilik anlayışında nasıl bir dönüşüm yarattığı ele alınacaktır.

\section{Eduatinment/Öğrence Mekânı Olarak Mardin Müzesi}

Tarihin laboratuvarları konumundaki mekanlar olan müzeler, toplumun kültürel mirasını toplayan, araştıran, koruyan, halkın eğitimi için sunan ve çă̆daş bir toplumda bulunması gereken temel kurumlardan biri olarak kabul edilmektedir. Kültürel mirasın korunmasında ve toplumsal hafızanın aktar1mında önemli bir role sahip olan müze, Uluslararası Müzeler Konseyi tarafından (ICOM) "toplumun ve onun kalkınmasının hizmetinde kâr amacı gütmeyen, eğitim, çalışma ve eğlence amacıyla halka açık, insanlığın ve çevresinin maddi ve manevi mirasını edinen, koruyan, araştıran, ileten ve sergileyen kalıcı bir kurum" olarak tanımlanmaktadır (Müze tanımı, ICOM).

Müzelerin temel işlevlerinden biri olan eğitim, müze koleksiyonu ile ziyaretçiler arasında iletişim kurmak amacıyla yapılan çalışmaları kapsamaktadır (Erdoğan, 2018, s. 13). Moffat ve Woollard (2004, s. 3)'a göre müzelerdeki eğitim etkinlikleri hem kültürel azınlıklar gibi ortak özellikleri olan grupları hem de yaratıcı ve karma programlar sayesinde bireyleri kendine çekerek yeni ziyaretçiler kazanmada önemli bir rol oynamaktadır. Clutterbuck (2008, s. 73)'a göre de seri üretimle çoğaltılmış ve dijital platformlarda kalitesi artırılmış imgelerle dolu günümüz toplumunda müzeler, insanların otantik ve gerçek objeleri bulabilecekleri mekanlardır. Böylece bu mekanlar, insanların geçmiş kültürleriyle arasında bir bağ kurulmasına yardımcı olmaktır. Ayrıca müzeler kişisel anlam yüklü mekanlardır. Yani bireyler kendi kişisel bilgi ve deneyimlerinden yola çıarak anlamları oluştururlar.

Müzeleri sadece informal eğitim/öğretim mekanları olarak değil hem formal hem de informal eğitim/öğretim mekânı olarak değerlendirmek mümkündür. Müzeye gelen ziyaretçiler hem müze mekanıyla hem de müzede sergilenen nesnelerle etkileşimde bulunarak farkında olmadan öğrenmeyi gerçekleştirirler. Bu eğitim informal eğitim olarak adlandırılırken; belli hedeflere 
yönelik planlı, programlı yapılan kurs, atölye vb. faaliyetler ise formel eğitim olarak görülmektedir (Tezcan Akmehmet ve Ödekan, 2006, s.55).

Mercin ve Alakuş (2005, s. 3-4)'a göre müzeler, yaratıcıllı̆g teşvik eden, yaparak-yaşayarak öğrenmeyi sağlayan, gerçek eserlerle öğrencileri buluşturan, geçmiş ile gelecek arasında köprü kuran, farklı uygarlıkların eserlerine saygıyı artırarak kültürlerarası karşılıklı anlayış geliştiren ve öğrenmeyi eğlenceli hale getiren mekanlardır. Benzer şekilde Mardin Müzesi'nin kendi tanıtım sayfasında da müzenin sadece tarihi eserlerin sergilendiği bir mekân olmasının ötesinde gerçekleştirilen eğitim faaliyetlerine vurgu yapılarak bu durum şöyle dile getirilmektedir:

"Mardin Müzesi, müzelerin "tarihi eserlerin korunduğu ve sergilendiğ $i$ yer" kimliğini aşarak topluma hizmet veren bilim ve eğitim merkezi olarak ziyaretçilerinin öğrenme süreçlerine etki eden, sosyalleşmelerini sağlayan, içinde bulunduğu kültürü ve farkh kültürleri derinlemesine tantan programlar geliştirmeye devam ediyor." (mardinmüzesi.gov.tr,_05.03.2019)

Yapılan görüşmelerde de bir katılımcı Mardin müzesinin mekânsal yapısindan ziyade gerçekleştirdiği eğitim faaliyetlerine vurgu yaparak bu faaliyetlerin müzeyi özel kıldığını ve kente renk kattığını belirtmektedir:

"Mardin müzesini benim için özel kılan binasının büyüklü̈̆̈̈nden ya da tarihi dokusundan ziyade yaptığı faaliyetlerdir. Başta çocuklar olmak üzere her kesime hitap etmeyi amaçlamakta ve onlar için etkinlikler düzenlemektedir. Örneğin her sene düzenlediği uluslararası uçurtma festivali hem Mardin Müzesi'ne hem de Mardin'e ayr bir renk katmaktadır." (Kadın, 26 yaşında, Öğretmen)

Erdoğan (2017, s. 84) da Mardin müzesi üzerine yaptığı çalışmasında yapılan bu etkinliklerin amacını "çocuklarda gözlem, mantık, yaratıcılık, bilim, sanat ve estetik olguları içinde eleştirel düşünme becerisi, hayal gücü ve keşif eğilimlerini geliştirerek kültürel mirasını tanıyan, koruyan ve yaşatan; farklılıklara saygı gösteren, demokrasi bilinci edinmiş, paylaşımcı, ulusal ve küresel problemlere yenilikçi, sağduyulu çözümler üretebilen, bilime değer veren müze kültürüne sahip nesillerin yetişmesini" sağlamak olarak belirtmektedir. Böylelikle müze kültürel faaliyetlere oyun ve eğitim ögelerinin katılmasıyla alışılagelmiş müze deneyiminin dışına çıkılmasına olanak tanımaktadır. Dolayısıyla kültürel mirası sergileyen mekân aynı zamanda eğitim ve eğlence faaliyetlerini içeren bir öğrence mekânına dönüşmüş durumdadır. 
Günümüzde eğitimin sadece kitap ve okulla sınırlı olmadığını belirten Çiftçi ve Acer (2015, s. 62), "duvarsız sınıf" olarak tanımlanan müzelerin eğitimde önemli mekanlar olduğunu belirtmektedir. Yapılan görüşmelerde de Mardin müzesi "duvarsız okul" modeli olarak tanımlanmakta eğlence ve eğitimin bir aradalığına dikkat çekilmektedir:

“Gelen öğrencilerimize müzemizi gezdirip teşhir salonlarndaki eserler aracılığıyla başka türlü bir tarih ve arkeoloji anlatısı gerçekleştiriyoruz. Müzemiz "duvarsı okul" modelinin en güzel mekanlarndan biri. Böylece çocuklara sanatı eğlenceli bir yolla sevdirmenin keyfini yaşıyoruz." (Kadın, 25 yaşında, Müze eğitimcisi)

Geleneksel müzelerdeki "dokunma ve uzak dur" anlayışının tersine "dokun ve keşfet" mantığıyla kurulan çocuk müzeleri çocukların yaparak ve yaşayarak öğrenmelerini temel almaktadır (Aktaş Arnas, 2017, s. 24). Hissetmeye dayalı olan dokunma duyusunun müzede aktif olarak kullanılması çocukların unutulmaz bir müze deneyimi yaşamalarını sağlamakla birlikte müze aracılığıyla eğitim ve öğrenme faaliyetlerinden en yüksek verimin alınmasına olanak tanımaktadır. Turanlı (2012, s. 82), müzede nesneler aracığıyla yapılan eğitimin yazılı bir belgeden veya sözden daha ilgi çekici olduğunu ve öğrenme işleminin odak noktasını oluşturduğunu belirtmektedir. Müze faaliyetleri anlatılırken hem yapılan görüşmelerde hem de müzenin kendi tanıtım sayfasında "yaparak ve dokunarak öğrenme"ye yapılan vurgu dikkat çekmektedir. Örneğin yapılan görüşmelerde bir katılımcı müzedeki faaliyetlerdeki yaparak ve dokunarak öğrenme vurgusunu şöyle dile getirmektedir:

"Her yaş grubunun seviyesine uygun eğitim modülleriyle, somut olmayan kültürel miras öğelerimizi ve kültür varlklarımızı koruma ve yaşatma farkındalı̆̆ amacın taşıyan eğitim etkinliklerimiz, yaparak ve dokunarak öğrenme deneyimiyle öğrencilerimizin hafizalarmdan uzun süre silinmeyecek bir güne dönüşmektedir" (Kadın, 23 yaşında, Müze eğitimcisi)

Aktaş Arnas (2017, s. 18), çocukların oyun oynayarak ve keşfederek kendiliğinden öğrenme imkânı bulduğu ve gelişimlerine eşsiz bir katkı sağlayan bir öğrenme ortamı olarak çocuk müzelerinin çocukların eğitiminde önemli bir yere sahip olduğunu belirtmektedir. Yapılan görüşmelerde de müze faaliyetlerinin çocukların eğitimine yönelik katkısı şöyle dile getirilmektedir:

"Bence her şeyden önce farkındalık kazandiruyor. Bir de gerçekten çocuklarm mutlu oldukları, yaparak yaşayarak öğrendikleri kahıı bir öğrenme olarak bir farkındalı yaratıyor. Müze gezisi içerisinde drama yaptırıyoruz. Oradaki 
eserlerle bağ kurmasını sağlıyoruz. Arkeolojik kazı çalışmaları yaptırıyoruz. Bütün atölyelerde çocuklar eğleniyorlar aslında. Eski çocuk oyunları oynatıyoruz eğleniyorlar. Ebru atölyesinde eğleniyor. İlk defa orada görüp ilk defa orada deneyimledikleri için çocuklara ilginç geliyor. Ebru yaptırırken, kök boya baskı yaptırırken de geçmiş ve geçmişle olan bă̆, atalarımızın yaptıkları, işte süslenme neden önemlidir? temel ihtiyaçlar üzerinden de eğitimcinin müze eğitim paketi içerisinde kazandırması gereken davranışlar nelerse o davranışlarla ilgili çaktırmadan oyunlaştırarak öğretmeye çalışıyoruz." (Erkek, 40 yaşında, Müze müdürü)

“Özellikle üzerinde durduğumuz şey okul ve müze farkı. Şimdi diyorlar ki okulda sadece ders görüyoruz. Okulda eğitim alyoruz. Öğretmenler var. Müzede tarihi eserler var. Müzeye gelene kadarki bilgi ve düşünceleri bu yönde. Ama ĕ̆itim etkinlikleri sonrasında yaptığımı görüşmelerde hayır burada da öğretmenler var. Burada da eğitim var. Çok keyif aldık, çok eğlendik. Bir daha gelmek istiyoruz. Keşke hep buraya gelsek. Üzerlerinde ne gibi bir dönüşüm oldu derseniz çocuklar şimdi okullarda çok sıkı bir eŏitim içerisindeler. Formal eğitim daha doğrusu. Türkçe, matematik, sosyal, fen gibi. Ama bizim burada yaptı̆̆ımız eğitimler daha çok sanatsal ve kültürel eğitimler. Çocuklar bu kültürü de öğrenmeli. Bir kültürel aktarm, o kültürün devamım să̆layabilmek ve çocuklara bunu deneyimletebilmek de önemli." (Kadın, 25 yaşında, Müze eğitimcisi).

Müzeler, kültürel mirasın korunup sergilendiği, gelecek kuşaklara aktarıldığı, eğitim amaçlı kullanıldığı ve halkı eğlendirici yönleri olan kurumlar olarak içerikleri, birikimleri ve çoğu zaman mekânsal konumlarıyla toplumsal belleğin gösterim alanlarıdır. Tarihsel veriler doğrultusunda ortaya konan 'görsel ögeler'le birlikte doğrudan veya dolaylı olarak tarih bilincinin oluşmasına katkıda bulunmakta ve toplumsal belleği oluşturmada önemli bir rol oynamaktadır (Mercin, 2003, s.112). Ayrıca toplumsal kimliği yansıtan müzeler kent tarihi ve kültürüne ışık tutarak şehrin imajını güçlendirmede de önemli rol oynayarak kente gelen turistlerin ziyaretlerini teşvik eden cazibe merkezleri olarak karşımıza çıkmaktadır (Ballofet vd., 2014, s.4).

Toplumun tarihi, kültürel, doğa vb. değerlerinin korunduğu ve eğitimsel amaçlarla sergilendiği mekanlar olan müzelerde koleksiyonların sergilenmesi öğrencilerin geçmişin nasıl yorumladı̆̆ını görmelerine olanak tanımakta; geçmiş ve tarih disiplini hakkında eleştirel düşünme becerilerinin gelişmesine katkıda bulunmaktadır. Dolayısıyla müzelerdeki informal eğitim 
ortamı öğrencilerin yaşayarak öğrenecekleri bir öğrenme ortamı hazırlayarak düşünme becerilerinin gelişiminde etkili olmaktadır (Dilli, 2017, ss.306-307).

Mardin müzesi Somut Olmayan Kültürel Miras Müzesi olarak da tanımlanabilir. Çünkü müzede sadece nesnelerin sergilenmesi değil aynı zamanda somut olmayan kültürel mirasın da yaşatılması ve korunması söz konusudur. Küreselleşmenin sonucu olarak yok olma tehlikesi altındaki kültürlerin korunması fikrinden doğan UNESCO tarafından 2003 yılında yapılan Somut Olmayan Kültürel Mirasın Korunması Sözleşmesi müzecilik anlayışına yön vermesinin yanı sıra kültür koruma yaklaşımlarına da yeni bir boyut kazandırmiştır. Böylelikle yeni bir sergileme yöntemini benimseyen somut olmayan kültürel miras müzeleri Tekin (2017, s. 157)'e göre müze ve ziyaretçi arasındaki sınırı kaldırarak müzede öğrenme modellerini ve müzecilikteki dönüşümü en iyi örnekleyen müze türlerinden biri olmuştur. Bu müzeler, sadece sergilenen nesnelerin tarihini anlatmamakta; ziyaretçilerin dokunabildiği sergileme yöntemleri ile nesneleri tanıma ve gündelik hayatın içerisinde anlamlandırmalarını sağlamaktadır.

Müzenin kültürel mirasın korunması konusundaki önemi yapılan görüşmelerde de sık sık dillendirilmiştir. Müzedeki faaliyetlerin asıl amacının da kültürel miras farkındalığı olduğu müze müdürü tarafından şöyle ifade edilmiştir:

"Asıl amaç kültürel miras farkındalı̆̆g. Kendini tanıyan, kendine yabancllaşmamış, kendi kültürünü ve kültürel değerlerini seven, ayraca bu değerlerin farkında olan bir toplum için aslında müze var. Biz de o amaçla ve onun bilincinde olarak hareket ediyoruz. Yoksa uçurtma da yapıyoruz, para da bastırıyoruz vs. ama bununla birlikte eğitimcilerin hepsi kültürel miras farkındalığını çocuklara aktarmaya çalışıyor." (Erkek, 40 yaşında, Müze müdürü)

Toplumsal hafızanın mekânda billurlaştığı müzede belleğin tekrar üretilerek yeni nesillere aktarımı sağlanmakta ve müze bir bellek mekanına dönüşmektedir. Bu durum katılımcılar tarafından şöyle ifade edilmektedir:

"Bir çocuk buraya geldiŏinde kök boya baskıyla geçmişte insanlarn fabrikalar olmadan, mağazalar olmadan kendi boyalarm yapıp, kendi kalıplarını oyup kendi kıyafetlerini süslediklerini öğreniyorlar. Yani yaptığımız şey sadece teorik bir aktarm da değil. Tamamen uygulamaya ve eğlenceye yönelik bir kültürel aktarım." (Kadın, 23 yaşında, Müze eğitimcisi) 
"Mardin müzesi Ekim ayında düzenledikleri Masal Buluşmalarn ile çocuklara, gençlere ve yaşlılara hitap etmektedir. Kaybettiğimiz değerleri kazandırmak adına çokça çalışma yapmaktadır ve bana göre birçoğunu kazandırmayı başarmıştır." (Kadın, 26 yaşında, Öğretmen)

Dilli (2017, s.305) müzelerin informal eğitim-öğretim alanları arasında etkili bir öğrenme ortamı sunarak teknolojik gelişmelerin sağladığı avantajlarla birlikte oluşturulan dijital ortamlar ve atölye çalışmalarıyla çocuklar için yeni bir eğlenceli müze ortamı yarattığını belirtmektedir. Özellikle çocuklara yönelik uygulamalara verilen önem müzelerin mekânsal tasarımını da etkilemekte; böylece müzeler çocuk mekanlarına dönüşmektedir. Benzer şekilde Mardin müzesinde yapılan faaliyetlerin önemli bir kısmının çocuklara yönelik olduğu görülmektedir. Hedef kitlesinin büyük kısmının çocuklardan oluşması, müzedeki eğitimin amaçlarının gerçekleşmesi için güzel bir zemin sağlamaktadır. Bu durum görüşmelerde şöyle dile getirilmiştir:

"Biz genel anlamda bu şehrin içindeki insanlarm kültürel zenginliği, çeşitliliği bilmesi ve somut olmayan değerleri kaybetmemesi için ne yapabiliriz kaygisıly hareket ediyoruz. Onun içinde küçük yaştan çocukları müzeyle haşır neşir etmeye çalışıyoruz. Bu şehirde 170-180.000 öğrenci var. Ortalama 200.000 diyelim. Bunun 110-120.000'i mutlaka müzeye gelmiştir. Küçük yaşta müzeyle buluşturmuşuzdur bu 10 yıl içinde." (Erkek, 40 yaşında, Müze müdürü)

Günümüzde hızlı kentleşme ve küreselleşmeyle birlikte sermaye akışını kolaylaştırmak ve birikimi artırmak için birer araca dönüşen kent mekânı, çocuklar için güvenli bir alan olmaktan hızla uzaklaşmaktadır. Kentsel donattların çocukların fiziksel ve sosyal gelişimi için yeterli olmadığı görülmekte; bu durum çocukların davranışlarını olumsuz etkilemektedir (Yalçınkaya, 2015, ss. 82-83). Dolayısıyla çocuklara yönelik eğitici ve eğlenceli faaliyetler tasarlayan Mardin müzesi kentteki sınırlı sayıda çocuk mekanlarından biri olması açısından çok önemlidir. Yapılan görüşmelerde de katılımcılardan biri müzenin çocuk mekanına dönüştüğünü şöyle ifade etmektedir:

“Eski Mardin'de yaşayan çocuklar bizim müdavimlerimiz. Mesela burada bizim sikke atölyesini anlattp uygulatabilecek öğrenciler, çocuklar var. Eğitmenler yetişiyor gerçekten. Sürekli ayakları burada. Çocuklarm yaşamminda bir müze var. Hani büyüdüklerinde bir Mardin müzesi vardı. Ben zamanımı hep orada geçirirdim. Şunları yapıyordum diye hatırlayacaklar." (Kadın, 25 yaşında, Müze eğitimcisi) 
Çocuklara yönelik yapılan faaliyetlerin çoğu zaman ücretli olması orta ve üst sınıfların bu faaliyetlere daha çok katılımını sağlamakta yoksul insanları ise dışlamaktadır. Müzedeki atölye çalışmalarının ücretsiz olması normalde büyükşehirlerde orta ve üst sınıf çocuklarına yönelik yapılan atölye çalışmalarına alt sınıfların da ulaşabilmelerini sağlaması açısından önemlidir. Dolayısıyla müzenin günümüz neoliberal politikalarla şekillenen kent mekânında sınıf farklılıklarının mekânsal olarak da ayrışmaya neden olmadığı ender mekanlardan birisi olduğu söylenebilir. Ayrıca yaz aylarında çocuklara yönelik ücretsiz yaz okulu faaliyetlerinin olması çocukların müzeye olan ilgisini daha da artırmaktadır.

Yapılan görüşmelerde de bazı katılımcılar bu durumdan bahsetmekte; müzedeki eğitim etkinliklerinin ücretsiz olmasının yaz okulu seçiminde önemli bir rol oynadığını belirtmektedirler.

"Valla ne yalan söyleyeyim çocuğumu yaz okulu olarak müzeye gönderdim. İki yıldır oraya gönderiyorum. Hem çok güzel ilgileniyorlar hem de bedava. Sadece servise para veriyoruz. Çocuğum da çok eğleniyor." (Kadın, 28 yaşında, Öğretmen)

“Çocuğumu yazm müzedeki yaz okuluna gönderdim. Diğer yaz okullarna da baktım ama uçuk fiyatlar vardı. Ben de uygun fiyatlı alternatifler aramaya başladım. Bu arada sosyal medyada Mardin Müzesi faaliyetleriyle karşllaştım. Oraya göndermeye karar verdim. Memnun da kaldık açıkçası." (Erkek, 41 yaşında, Akademisyen)

Müzedeki faaliyetler sadece çocuklarla da sınırlı kalmamakta diğer yaş gruplarına da hitap etmektedir. Buradaki faaliyetlerle ilgili belirtilmesi gereken bir husus da yaş grubu ne olursa olsun yapılan etkinliklerin kültürel mirasın devamına yönelik olduğudur.

“Çocuklar dışında halka yönelik mesela mahalledeki kadınlara yönelik yemek atölyemiz, sedefatölyemiz, dikiş nakış atölyemiz var. Hani onlarm kendi geleneksel el sanatların devam ettirebilmesi için. Geleneksel müziğin yaşaması için de leyli programmmz var aynca. Cumartesileri düzenliyoruz. Ve orada dışarıdan gelen de Mardinli olan da var. O müziğin yaşayabilmesi ve aktarnlabilmesi müziğin dinlenip söylenmesiyle mümkün olan bir şey. Ona da nereden baksanı 10.000'in üzerinde insan katıldı şu iki yılın içinde." (Erkek, 40 yaşında, Müze müdürü) 


\section{Mardin Müzesi'ndeki Edutainment/Öğrence Etkinlikleri}

Küreselleşme ve teknoloji alanında meydana gelen önemli değişmelerle birlikte müzeciliğin doğasında da değişim ve dönüşümler yaşanmıştır. Sadece kültürel mirasın toplanıp korunması, saklanması ve sergilenmesi olarak ortaya çıkan klasik müzeler yerine günümüzde toplumla etkileşimli bir çağdaş müzecilik anlayışı ortaya çıkmıştır (Altunbaş ve Özdemir, 2012, s.1). Yine klasik müzecilikteki durağan mekân anlayışından yeni yöntemlerin kullanımıyla birlikte yaşayan çağdaş müzecilik anlayışına doğru bir dönüşüm yaşanmaktadır (Şar ve Sağkol, 2013, s.84).

Teknolojideki önemli gelişmelerle birlikte ortaya çıkan edutainment/öğrence uygulamaları eğitim, tüketim ve eğlence alanlarında önemli etkiler yapmakla birlikte kültürel mirasın korunmasını ve aktarılmasını sağlayan kurumlar olan müzeler üzerinde de önemli değişim ve dönüşümlere neden olmuş durumdadır. Addis (2005, ss.730-734) de benzer şekilde edutainment/öğrence uygulamalarının yükselişiyle birlikte yeni teknolojilerin sanat ve kültür dünyasında da uygulanmaya başladığını belirtmektedir. Ona göre sanat ve kültür tüketimi, bireylerin aynı anda hem zevk alması hem de öğrenmesi gibi bir eğlence biçimi olarak da yorumlanabilir. Örneğin, yeni teknolojilerin müzelerde eğlenceli bir öğrenme sürecinin oluşması için kullanılması müze ziyaretçilerinin öğrenme süreçlerinin daha kalıcı olmasına neden olmakta ve unutulmaz bir müze deneyimi yaşamalarını sağlamaktadır.

Müzelerin son yıllarda eğlence parklarına benzemesi gerektiği fikrinin ortaya çıktığını belirten Ballofet, Courvoisier ve Lagier (2014, s. 4), geleneksel olarak birbirleriyle zıt iki formun bir araya gelişiyle sınırların adeta bulanıklaştığını belirtmektedir. Onlara göre popüler kültürü temsil eden eğlence parkları yüksek kültürü temsil eden müzelerle iç içe geçmiş durumdadır. Başka bir deyişle müzeler ve eğlence parkları arasındaki gözenekliliğin artmasıyla karakterize edilen bu durum müzelerin hem kültürel hem de eğlence faaliyetlerini içeren hibrit mekanlara dönüşmesine neden olmuştur.

Mardin Müzesi bünyesindeki edutainment/öğrence uygulamalarına bakacak olursak hiç şüphesiz başta birçoğu çocuklara yönelik tasarlanan atölye etkinlikleri gelmektedir. Örnek vermek gerekirse heykel ve kil tablet, seramik, sikke yapımı, kök boya baskı, Karagöz, bakır işleme, uçurtma, ebru yapımı, bez bebek yapımı, ahşap yakma, geleneksel çocuk oyunları ve masal atölyesi gibi 30'u aşkın atölye çalışması yapılmaktadır. Bu atölye çalışmaları 
kış okulu ve yaz okulu bünyesinde düzenlenmekte ve özellikle çocuklara yönelik olduğu belirtilmektedir. Okulların yıl sonu tatil döneminde (1 Temmuz30 Ağustos tarihleri arasında) gerçekleştirilen yaz tatili etkinliklerinde yapılan atölye çalışmalarının amacı ise bir yandan çocukların kültürel varlıkları tanımaları ve kültürel mirasın korunmasına yönelik bilinç kazanmalarını sağlamak diğer yandan da eğlenerek öğrenmelerine imkân tanımaktır.

Müzedeki edutainment/öğrence uygulamalarına bir örnek vermek gerekirse kök boya baskı atölyesinde çocuklar kök boyalarıyla hazırlanan çeşitli renklerdeki doğal boyaları kullanarak kumaş üzerine baskı yapmaktadırlar. Bu şekilde çocuk, Mardin'in kendi kültürel mirasında önemli bir yer tutan baskı boyamayı yaparak yaşayarak öğrenirken eğlenerek zamanını güzel geçirmektedir.

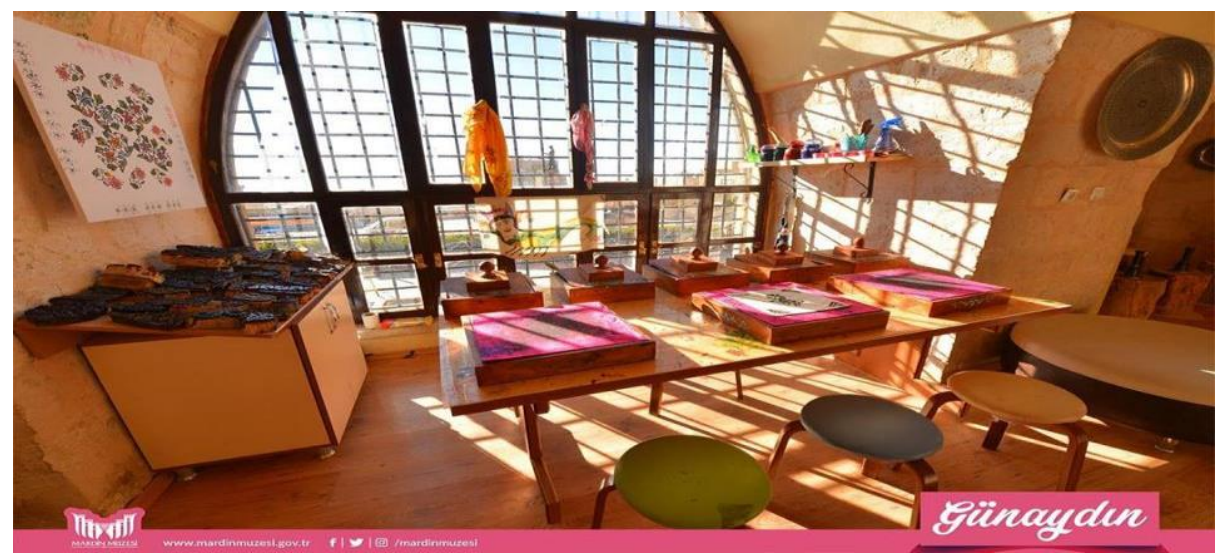

Şekil 1. Kök Boya Baskı Atölyesi

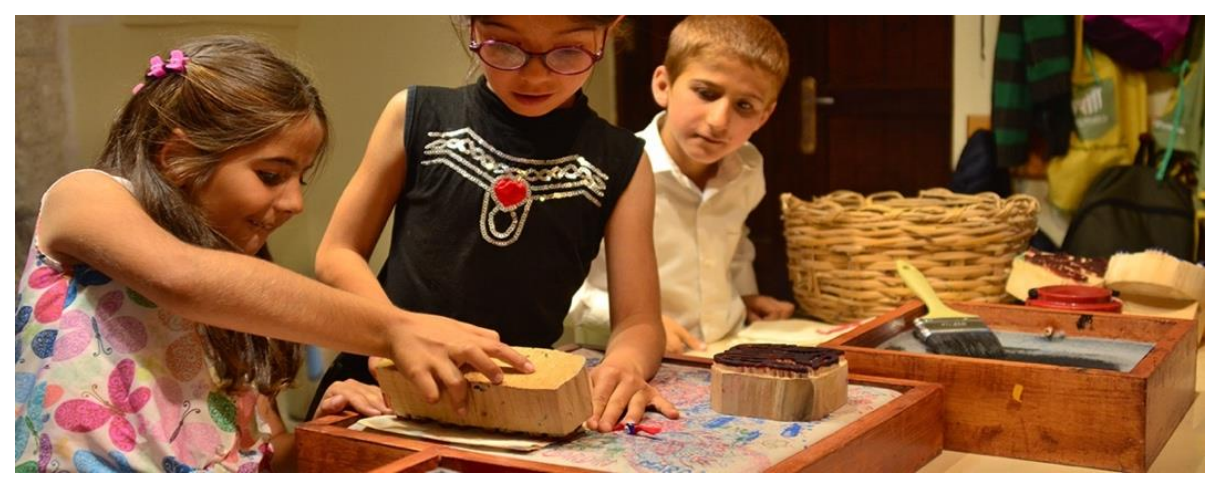

Şekil 2. Kök boya baskisı yapan çocuklar 
Yine sikke (para) basım atölyesinde de çocuklar öncelikle paranın nasıl ortaya çıktığıyla ilgili bilgi edinmekte ve daha sonra kendileri sikke basımı yaparak hatıra paralara sahip olmaktadırlar. Yapılan görüşmelerde de bu deneyimi yaşayan herkes -özellikle çocuklar- çok heyecanlandıklarını ve mutlu olduklarını ifade etmişlerdir:

"Ben Mardin müzesine gittiğimde kendi paramı kendim yaptım. Cüzdanımda saklıyorum. Uğurlu param oldu benim." (Kadın, 12 yaşında, Ortaokul Öğrencisi)

"Mardin müzesine okulla birlikte gittik. Orada paranın tarihini öğrendik ve strayla para bastık. Çok eğlenceliydi. Eskiden insanlar nasıl para basıyormuş onu gördük." (Erkek, 11 yaşında, Ortaokul Öğrencisi)

"Mardin müzesine gittiğimde hatıra olarak baskı yaptım. Bez verdiler ona baskı yaptım. Onu hatıra olarak saklıyorum. Normalde dişarda da satılıyor o bez. 67 lira vardır fiyatı. Ama müzede bedava verdiler. Müzeden çıtı̆̆ımda elimde hatıra olarak saklayabileceğim ve kendi yaptığım bir eşyanın var olması hoşuma gitti açıkçası." (Kadın, 20 yaşında, Üniversite Öğrencisi)

"Özellikle Artukluların bastı̆̆ı paranın bir örneğinin isteyen ziyaretçilere ücretsiz olarak bizzat kendisi tarafindan bastırlarak ona hediye edilmesi bize çok güzel bir jest oldu. Etkileyiciydi." (Erkek, 35, Mühendis)

"3. sinıftayken okulla birlikte Mardin müzesine gittim. Arkeoloji parkında kazı yaptık arkadaşlarımla. Kaşık bulmuştum. Bir tane vazo bulmuştum. Bezlere baskı yaptık ve para bastık. Arkadaşlarımla çok eğlenceli vakit geçirdik." (Erkek, 13 yaşında, Ortaokul öğrencisi)

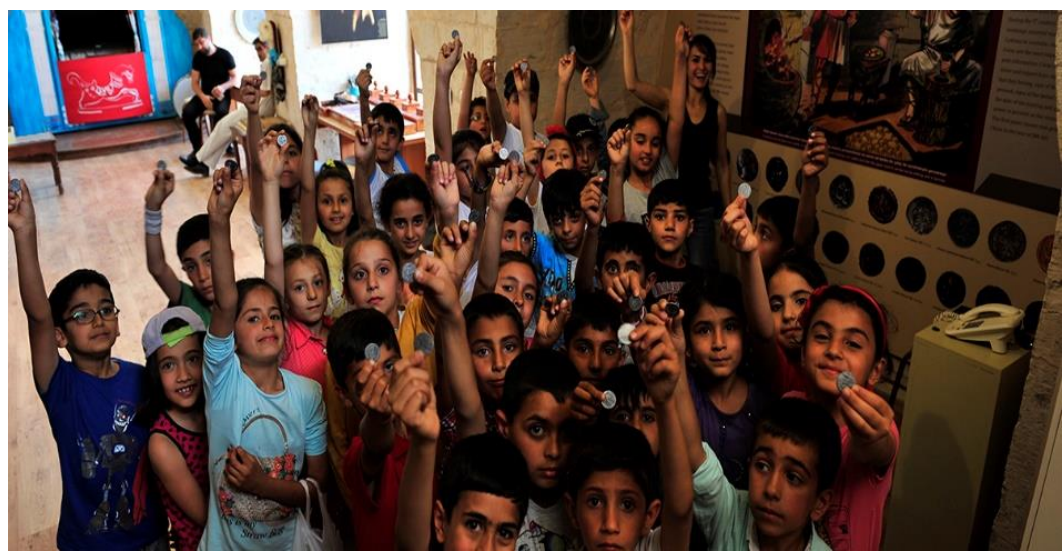

Şekil 3. Kendi hatıra sikkelerini basan çocuklar (Mardin Müzesi, t.y) 
Müzede geleneksel çocuk oyunları ve masal anlatıcılığı gibi atölye çalışmaları yapılmakta; somut olmayan kültürel miras çocuklara tanitılmakta ve aktarılmaktadır. Yapılan görüşmelerde bu durum şöyle ifade edilmiştir:

"Somut olmayan kültürel mirasın da iş programı içerisine giren müzelerdeniz. Sadece kendi koleksiyonumuz üzerinden işte buradaki eserlerin ziyaretçiye ulaşmasıyla ilgili bir alt yapının yanı sira aslında halkm kültürünün yaşaması ve buradaki koleksiyonu ve buradaki kültürrü değgrli bulan insanlar yaratmak. Geleneksel kök baskı boyama atölyesi var, tablet atölyesi var, yazı var, arkeolojik kazı var, dikiş nakış atölyesi var. Yetişkinlere yönelik kurslarımız var. Sedefatölyesi var. Cam altı var. Şu an yemek atölyesine başladık. Yemek atölyeleri var. Geleneksel yemeğin devamına yönelik. Aslında somut olmayan kültürel mirasin yaşamasina yönelik yapılması gereken ne varsa burada biz kendi kapasitemiz doğrultusunda yapmaya çalş̧ıoruz." (Erkek, 40 yaşında, Müze müdürü)

Tekin (2017, s.162)'e göre, somut olmayan kültürel miras unsurlarından olan sözlü anlatımlar toplumda ve özellikle çocuklarda aidiyet duygusunu geliştirmekte; kültürel çeşitliliğin gelecek kuşaklara aktarımını sağlayarak ortak bir bellek oluşturmaktadır. Ölçer (2004, s. 89) de benzer şekilde müzelerde çocukların sadece masal dinlemesi değil aynı zamanda masal anlatııllğına teşvik edilmesinin geleneğin sürdürülebilirliği açısından önemli olduğunu belirtmekte böylece çocukların hem alıcı hem de aktarıcı rolüne bürünebileceklerini ifade etmektedir.

Yapılan görüşmelerde de katılımcılar kültürel mirasın devamını sağlayan bu atölye çalışmalarını olumlu karşılamakta, çoğu zaman çocuklarını müzeye getirmelerinin asıl amacının Mardin' in kültürel mirasının devamını sağlayarak nesiller boyunca yaşamasını istemeleridir.

“Mesela ben çocuğuma Mardin'imize ait kültürel değerleri nasıl aktarayım. Böyle bir imkânım yok. Örneğin kök baskı boyama Mardin'e has özel bir sanat. Bunu çocuğum müzede deneyimleyerek öğreniyor. Eve gelip bana anlattığında ve yaptıkların gösterdiğinde ben çok mutlu oluyorum. Kimliğimiz, kültürümüz yaşıyor bu sayede." (Erkek, 35 yaşında, Doktor).

"Çocuğum bizim küçükken oynadığımı oyunları müzede oynuyor. Geleneksel çocuk oyunlarımızın yaşatılması bu devirde çok önemli. Biliyorsunuz şimdiki çocuklar bırakın sokakta oynamayı ellerinden tablet ve telefon düşmüyor. Arkadaşlarıyla bir iletişimleri yok. Sosyal değiller. Ama müzeye gittiğinden beri çocuğumdaki değişimi fark ediyorum. Bu çok güzel bir durum. 
Keşke çocuklara yönelik bu faaliyetler hep olsa." (Kadın, 45 yaşında, Memur)

Atölye çalışmalarının dikkat çeken bir yanı da çocuğun geçmişle bağlantı kurmasını sağlayarak kültürel mirasını tanımasının eğlenceli bir yolu olmasıdır. Çocuk, kitaplardan öğreneceği bilgileri yaparak ve yaşayarak öğrenmekte ve bu eğitim faaliyetine oyunun da katılmasıyla birlikte hatırda kalıcı bir deneyim ortaya çıkmaktadır. Bu durum, çocukların müzeye karşı olan tutumlarını etkilemekte müzeyi sessiz olunması gereken, sadece vitrinlere bakılıp çıkılan bir yer değil eğlenerek öğrenilen bir mekân olarak algılamalarını sağlamaktadır. Dolayısıyla müzelere karşı olumlu tutum geliştirilmesine yardımcı olan edutainment/öğrence uygulamaları çocukların müze müdavimliğini artırmaktadır. Bu durum müzenin internet sayfasında şöyle ifade edilmektedir:

"Mardin Müzesi, Arkeopark ve diğer müze eğitimi alanlarryla birlikte bolca oyunların oynandığı, birbirinden farklı ĕgitici çalışmalarm yapıldı̆̆ı, zilin hiç çalmadı̆̆ı fakat çocukların hiç sıkılmadı̆̆ı, kahkahanın hiç eksik olmadığı bir yerdir. Eğlence ve sohbet, adımlar bahçesine atıldığı anda başlıyor müzede. Çocuklar oyunlarla eğlenirken, bugüne kadar hiç duymadıklan çok ilginç bilgileri de yaparak ve yaşayarak öğreniyorlar." (Mardin Müzesi, 10.03.2019)

Özer ve Polat (2019, s.1) da çocukların hayal gücünü, yaratıcılı̆̆ını, tarihsel düşünme becerisini destekleyen müzelere gitme alışkanlığının erken yaşta kazanılması gerektiğini belirterek çocukların müzelerle okul öncesi dönemde tanıştırılmasıyla müzelerin eğitici ve eğlenceli bir yer olduğu duygusunun onlara rahatlıkla verilebileceğini ifade etmektedir. Benzer şekilde yapılan görüşmelerde de bu durum müze yetkilileri tarafından sık sık dile getirilmektedir:

"Her şeyden önce buraya gelen çocuğu mutlu ediyoruz. Belli bir farkındalık kazandırmaya çalışıyoruz ve farkındalıkla gittiklerini düşünüyoruz. Tabi yaparak yaşayarak öğrenme ve interaktif bir öğrenme alanı yarattığınızda öğrenme daha kahıı oluyor. Tabi eğleniyorlar, oynuyorlar. Özellikle oyun oynarken çocuğun öğrenmesi çok önemli." (Erkek, 40 yaşında, Müze müdürü)

"Bu işin en güzel tarafi hem karşı tarafi memnun etmek hem de müze bilincini aşılamak. Çocuğa müzenin sadece teşhirden ibaret olmadığını, bu müzelerin başka şeyler de katabileceğini göstermek. Burada kök boya baskı olsun, 
sikke olsun, Karagöz olsun, cam altı olsun. Bunlarn öğrencilerdeki o bilinci uyandırmak, onu deneyimleyerek yapması daha çok iz bırakıyor onlarda. Tekrar tekrar gelmek istiyorlar. Illk geldiklerinde böyle durgunlar. Yarmm saat geçtikten sonra, tanışmalar olduktan sonra artık öğrenciler açılıyorlar. Gerçekten de giderken de hem sevinçli gidiyorlar hem de üzgün gidiyorlar. Çünkü gitmek istemiyorlar buradan." (Kadın, 23 yaşında, Müze eğitimcisi)

Mardin Müzesi'nde çocuklara yönelik diğer bir edutainment/öğrence faaliyeti ise arkeopark uygulamasıdır. Yapay bir arkeolojik kazı alanı oluşturulan bu etkinlikte çocukların gruplar halinde belirlenmiş alanlarda kazılar yaparak tarihi eser bulmaları sağlanmaktadır. Arkeopark bir anlamda arkeolojinin çocuklara tanıtılarak ve oyun şeklinde kazı yapmaları sağlanarak müze eğitiminin verildiği öğrence mekanıdır. Burada belirtilmesi gereken bir husus da müzedeki yapay bir kazı alanı olarak arkeopark alanının gerçek bir kazı alanının simüle edilmiş hali olmasıdır. Burada hem bir mekânın hem de bir mesleğin (arkeolog) simüle edilmesiyle gerçeğe benzeyen bir yapay dünyanın çocuklara sunulduğu görülmektedir. Bu simülasyon eğitim ve eğlenceyi bünyesinde barındırarak çocukların gerçek dünyadaki bir toplumsal rolü öğrenmelerine imkân tanımaktadır.

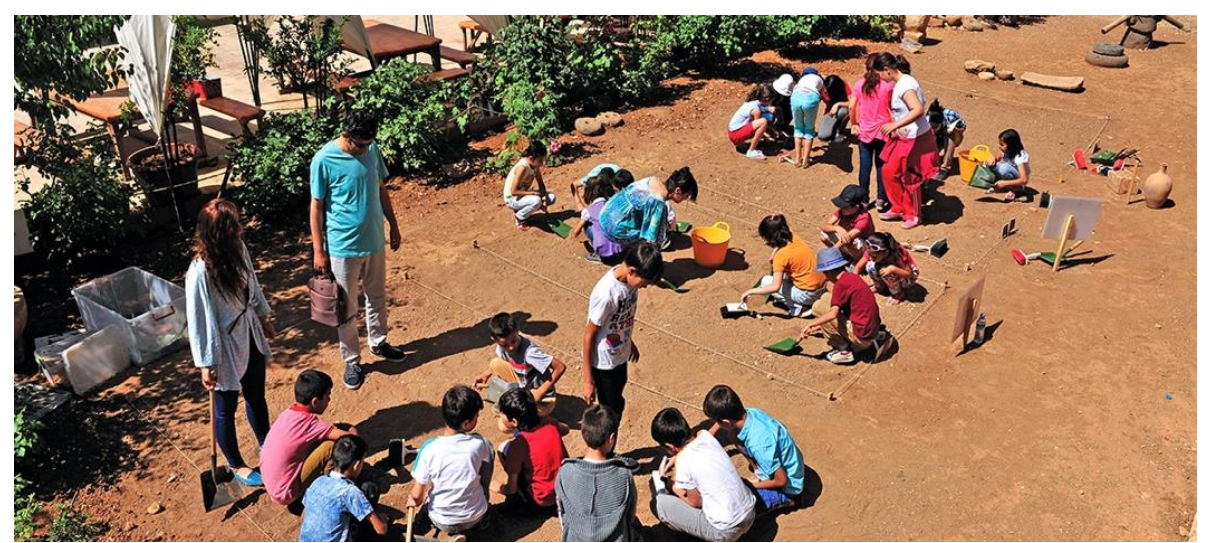

Şekil 4. Arkeopark'ta kazı yapan çocuklar (Mardin Müzesi, t.y)

Müzelerin edutainment/öğrence faaliyetlerini içermesi yeni bir müze gerçekliği ile birlikte ziyaretçilerin aktif katılımını sağlayarak unutulmaz bir deneyim kazanmalarını amaçlamaktadır (Ballofet vd., 2014, s.5). Eğitim faaliyetlerine verilen önem, müzenin bütün faaliyetlerini şekillendirdiği gibi 
mekânsal yapısını da etkilemektedir. Bu bağlamda Mardin müzesindeki mekânsal yapının düzenlenmesinde eğitim faaliyetlerinin ve atölye çalışmalarının dikkate alındığı görülmüştür. Bu durum müze müdürü tarafından şöyle ifade edilmiştir:

"Biz müzenin teşhir tanzimini yaparken en altta eğitim atölyelerini düzenlendik. Ondan sonra yukarıya doğru çıkıyorsunuz. En iyi alanlarımızı biz müze eğitimine ayırdık aslında." (Erkek, 40 yaşında, Müze Müdürü).

Dünyada müzelerdeki edutainment/öğrence uygulamalarına daha çok Amerika ve Avrupa ülkelerindeki çocuk müzelerinde rastlanmaktadır. İlk çocuk müzesi 1899'da New York'da açılan Brooklyn Çocuk Müzesi'dir. Çocuk Müzeleri Birliği'ne (ACM) göre dünyada toplam 22 ülkede 341 çocuk müzesi vardır. Dünyada gün geçtikçe sayıları artan çocuk müzelerinin sayısı ülkemizde ne yazık ki çok azdır. 90'lı yılların sonlarına doğru Türkiye'de bazı müzelerin içerisinde yer alan sınırlı sayıda "çocuk müzesi bölümü" bulunmaktadır (Aktaş-Arnas, 2017, s. 26-27). 2017 yılında da Ankara'da Mamak Belediyesi tarafından Kent Park Projesi içerisinde ilk çocuk müzesi açılmıştır. Ancak Mardin Müzesi bünyesinde barındırdığı faaliyetlerle uzun zamandır çocuk müzesine dönüşmüş durumdadır. Başka bir deyişle Mardin Müzesi'nin Türkiye'deki müzeler içerisinde öncü çalışmalar yaparak bir çocuk müzesi konumuna geldiği söylenebilir. Bu durum yapılan görüşmelerde de şöyle ifade edilmiştir.

"Diğer müzelerde çok az atölyeler var. Çok belli başlı. Mesela Anadolu Medeniyetler Müzesi'nde de sikke atölyesi var. Ama buradaki gibi değil. Ayda bir grup alyyor. Sadece birkaç grup alıyorlar. Tek kalıp ya da bir iki kaliplarn var diye biliyorum. Arkeolojik kazı yine Erimtam müzesinde var Ankara'da. Onlar da sadece yazin ayda bir grup alarak yapiyorlar ve bizdeki gibi bir alana sahip değiller. Şimdi Mardin Müzesi mekânsal olarak imkânı çok güzel. Birçok müzede bu avantaj yok. Yine ellerinden geldiğince yapiyorlar. Yine somut olmayan kültürel miras müzesinde Ankara'da kök boya baskl, ebru sanatı yine geleneksel sanatlar üzerine atölyeler var. Mardin Müzesini ayıran şey çok daha geniş bir kitleye ve çok daha sistematik, düzenli ve çok daha profesyonel çalışması. Çok daha sürdürülebilir bir müzecilik var." (Kadın, 23 yaşında, Müze eğitimcisi)

"Şöyle söyleyeyim çok müze gezip gördüm hayatım boyunca. Ama ben Mardin müzesine gelene kadar müzelerden nefret ediyordum. Soğuk, donuk, cansız, hissiz bir şey. Burası benim o yargımı çok kırdı. Çünkü burada başka bir 
şey var. Türkiye'de olmayan bir şey var burada. Zaten Avrupa'da aşıldı bu durum. Avrupa bizim Türkiye'de verdiğimiz mücadeleyi daha 50'lerde 60'larda vermeye başlamışlardı. Orada müze eğitimi etkinlikleri dediğimiz şey almış yürümüsş durumda. Türkiye'de Mardin müzesiyle bu biraz değişmeye başladı. Birçok müze bizi rol model olarak alıyor zaten. Çünkü Türkiye dendiğinde Mardin müzesi deniliyor. Uluslararası düzeyde ödüller almış, uluslararası camiada bilinen bir müze." (Kadın, 25 yaşında, Müze eğitimcisi)

Dünyada müze eğitiminde eğlenceli unsurların kullanılmasının bir nedeni müzelere gelen ziyaretçi sayısına göre müzeye bütçe ayrılmasıdır. Courvoisier, Courvoisier ve Jungen (2010), de müzelerin edutainment/öğrence uygulamalarına geçmesinin nedeninin maddi nedenlere bağlı olduğunu belirtmektedir. Bu kurumların alacağı bütçe, çoğu zaman katılım oranına yani müzelerin aldığı ziyaretçi sayısına bağlı olmakta bu durum da katılım rakamlarını korumak veya artırmak için müzeler üzerinde baskı kurmaktadır. Bu nedenle müzeler özellikle genç ve çocuk ziyaretçilere vurgu yaparak daha eğlenceli ve etkileşimli gösterimlerle yeni ziyaretçileri cezbetmek için çaba sarf etmektedirler (akt: Ballofet vd., 2014, s. 6). Denilebilir ki edutainment/öğrence uygulamaları müzelerin ziyaretçi sayılarını artırmak için kullandıkları bir araca dönüşmüştür. Ancak bu durum Türkiye'deki müzeler için söz konusu değildir. Çünkü Türkiye'de müzelere belirlenen bütçe müzenin ziyaretçi sayısına göre belirlenmemektedir. Bu durum da Türkiye'deki müzelerde edutainment/öğrence uygulamalarının gelişmesi önünde bir engel olarak görülebilir.

Mardin Müze deneyimlerini başka müze deneyimleriyle karşılaştıran bir katılımcı müzedeki rahat ortamın diğer müzelerde olmadığından bahsetmektedir:

“Ben İzmir'de Etnografya müzesine gittim. Orada bir görevli vardı. Nereye gidersem peşimdeydi. Ben bakmak istediklerime tam bakamıyordum. Rahatsiz oluyordum. Ama Mardin Müzesi'nde çok rahattım. Odadan odaya geçiyordum. Kimse peşimizde dolanıp bizi rahatsiz etmiyordu. Ama istediğimizde gelip anlatabileceklerini belirtiyorlardı. Bu durum benim hoşuma gitti. Kendimi sıkılmış hissetmedim bu müzede." (Kadın, 20 yaşında, Üniversite öğrencisi)

Katılımcılardan biri Mardin müzesindeki edutainment/öğrence faaliyetlerinin çoğu zaman diğer müzelere de örnek olduğunu belirtmektedir. 
“O klasik müze anlayışından teklif de alıyoruz. Bir grup geliyor mesela Balikesir'den TEV'in bilmem nesi. Sizi davet etmek istiyoruz diyorlar. Ankara'dan birileri geliyor biz sizi davet etmek istiyoruz diyorlar. Hem eğitim istiyorlar. Hem de atölye yapmamizı istiyorlar. Mesela Ankara'ya gidiyoruz haftaya. Bu sene Göbeklitepe yılı ilan edildi. Kültür bakanlı̆̆ınn bir çalışması. Önce İstanbul'a gitti arkadaşlarmmı. Orada 3 gün boyunca müze eğitimi etkinlikleri yapıldı. Haftaya da Ankara'da yapılacak." (Kadın, 25 yaşında, Müze eğitimcisi)

Görüldüğü gibi Mardin müzesi edutainment/öğrence faaliyetleriyle klasik müzecilik anlayışından uzaklaşarak toplumla etkileşimli çağdaş müzeciliğin bir örneğini sunmaktadır. Bu faaliyetler müze ziyaretçileri için eğlenceli ve unutulmaz bir müze deneyimi geçirmelerini sağlamanın yanı sıra müzeyi özellikle kentin çocukları için bir çocuk mekanına dönüştürmektedir. Ayrıca müze yaptığı faaliyetlerle Türkiye' de dünyadaki müzecilik anlayışının bir örneğini sunmaktadır.

\section{Sonuç}

Kültürel mirasın korunması ve aktarılmasında önemli bir role sahip olan müzeler, sadece eserlerin vitrinlerde sergilendiği ve ziyaretçilerin bakarak geçtiği bir mekân değildir. Aksine günümüzde ziyaretçilerinin aktif olarak müzeyle etkileşime geçtiği, dokunarak ve yaparak öğrenmenin vücut bulduğu, eğlence ve eğitimin mekânsal olarak kesiştiği öğrence mekanlarına dönüşmüş durumdadır.

Somut olmayan kültürel miras müzesi olarak da tanımlanabilen Mardin Müzesi geleneksel müzecilik anlayışının aksine çağdaş müzecilik anlayışı doğrultusunda düzenlediği etkinlik ve atölye çalışmalarıyla eğlenceli müze eğitimini özellikle çocuklara yönelik faaliyetlerle gerçekleştirmektedir. Müzedeki kültür ve eğlence faaliyetlerinin iç içeliği müzenin eğlence parklarına benzemesine neden olarak bir anlamda melez/hibrit bir mekansallık oluşturmaktadır. Bu melez mekânda müze ve eğlence parkı arasındaki gözeneklilikler artarak bir anlamda zıt gibi görünen bu iki mekânsal formun sınırlarının bulanıklaşmasına neden olmaktadır. Eğlence ve eğitimin bir aradalı̆̆ı anlamına gelen öğrence (edutainmenet)nin mekânsal olarak billurlaştığı bu müzede asıl amaç somut olmayan kültürel mirasın korunması ve yaşatılmasıdır. 
Özellikle çocuklara yönelik faaliyetlerde kültürün yeni nesillere aktarımı sağlanmaya çalısılmaktadır.

Dokunarak ve yaparak öğrenme modelinin uygulandığı müzede çocuklar formal eğitim (okul) dışında informal bir eğitim almaktadırlar. Böylece müze okul dışı eğitim faaliyetleriyle informal bir eğitim mekanına dönüşmüş durumdadır. Dolayısıyla "duvarsiz sinif" veya "duvarsiz okul" benzetmeleri de bu duruma gönderme yapmaktadır.

Müzede her yaş grubundaki bireylere yönelik faaliyetler olmasına rağmen yapılan çalışmaların büyük çoğunluğu çocuklara yöneliktir. Hedef kitlesinin önemli bir kısmının çocuklardan oluşması müzedeki eğitimlerin çocuklara yönelik olarak eğlenceli bir içerikle tasarlanmasını mümkün kılmıştır. Böylece müze kentte çocuklara yönelik eğitici ve eğlenceli faaliyetler tasarlayan sınırlı sayıdaki çocuk mekanlarından biri haline gelmiştir. Ayrıca bu durumun ziyaretçiler üzerinde olumlu etkiler bırakarak müze müdavimliğini artırdığı da gözlenmiştir.

Günümüz neoliberal politikalarla şekillenen kent mekânında karşılaşılan sınıfsal farklılaşmaların mekânsal ayrışmaya dönüşümü Mardin Müzesi'nde görülmemektedir. Bu durum sınıfsal ayrım olmaksızın toplumun bütün kesimlerinden bireylerin müze faaliyetlerine ücretsiz bir şekilde katılımını sağlayarak eşitlikçi bir kent mekânı ortaya çıarmaktadır.

Müzedeki çocuk atölyelerinde yapılan çalışmalar hem kent çocuklarının hem de ailelerin ilgisini çekmektedir. Somut olmayan kültürel miras unsurlarının ve kültürel çeşitliliğin yeni kuşaklara aktarımını sağlayan bu faaliyetler ortak bir toplumsal belleğin oluşmasını da sağlamaktadır. Kültürel kimliğin devamını sağlamının eğlenceli bir yolu olan atölye çalısmalarıyla yapılan eğitim faaliyetleri müzeyi eğlenerek öğrenilen bir mekâna başka bir deyişle öğrence mekanına dönüştürmüş durumdadır. Sonuç olarak eğlence ve eğitimin mekânsal olarak kesiştiği bu öğrence mekanının ürettiği yeni mekânsallıklar diğer müzelerin mekânsal üretimi üzerinde de etkili olduğu söylenebilir. 


\title{
EXTENDED ABSTRACT
}

\section{A Transformation of a Museum: Mardin Museum as an Edutainment Environment}

\author{
* \\ Nazife Gürhan \\ Mardin Artuklu Üniversitesi
}

Museums, which hold an important place in the preservation of the cultural heritage, both shed light on the cultural history of the city and serve as a bridge between the past and the present, realizing the transfer of this heritage to the new generations. Museums, possessing an important role in cultural heritage education, has become distant from the traditional museology and established an out-of-school learning environment through practices and trainings for children, who are one of their main target groups.

The main subject of the study is the transformations prompted by the edutainment practices in the museum structure and the differentiations they have revealed in the understanding of museology. In this context, the reflections of edutainment practices that emerged with the altering understanding of museology on the Mardin Museum are discussed in this study. Revealing how a place that contains cultural heritage elements transforms into a student space where education and entertainment spatially intersect is the main purpose of this study. In the study, based on the participants' museum experiences, it has been tried to reveal their relations with the museum. Concordantly, what the edutainment practices for children are in the Mardin $\mathrm{Mu}-$ seum, how these practices affect children's relations with the museum, and what the effects of edutainment practices on the museum structure are the other questions that the study tries to answer.

The case study, which is one of the qualitative research methods, was utilized as the research design in the study. In the study, semi-structured indepth interviews were conducted for the process of data collection. Within this context, in-depth interviews were held with 3 museum officials and a total of 18 people, 15 of them being from various age groups ranging from 11 to 50 years old, who participated in the workshops in the museum. Interviews were conducted through the random sampling system among the partici- 
pants who utilized the museum workshop. The data was also tried to be collected via performing participant observations. Another method utilized within the scope of the study was the document analysis. In this context, the web page of the museum was examined, and it was tried to be revealed how they constructed themselves on a discursive level based on their promotional articles.

Mardin Museum, which can also be defined as a non-concrete cultural heritage museum, provides an entertaining museum education with activities especially targeting children, through the activities and workshops it conducts in line with the understanding of contemporary museology, contrarily to the conventional museology understanding. Through prompting the museum to resemble amusement parks, the integrity of the cultural and entertainment activities in the museum establishes a hybrid/amalgam spatiality in a sense. In this hybrid place, the porosity between the museum and the amusement park augments, prompting the boundaries of these two spatial forms, which seem to be in a sense opposite, to blur. In this museum, where the edutainmenet -the combination of entertainment and education- spatially crystallizes, the main objective is to protect and preserve the non-concrete cultural heritage. Especially in activities targeting children, the conveyance of the culture to the new generations has been tried to be realized.

In the museum, where the model of learning by touching and doing is applied, children receive an informal education other than formal education (school). Thus, the museum has turned into an informal education place through its out-of-school educational activities. Therefore, the metaphors 'classroom without walls' or 'school without walls' also refer to this situation.

Even though there are activities for individuals of all age groups in the museum, the majority of the activities target the children. The fact that a significant portion of its target group consists of children made it possible for the trainings in the museum to be designed in an entertaining content for children. Thus, the museum has become one of the limited number of children's venues in the city that designs educational and entertaining activities for children. Additionally, it has been observed that this situation had a positive effect on the visitors and increased the frequency of people visiting the museum.

The transformation of class differentiation into spatial segregation, which is structured by the today's neoliberal policies and encountered in the urban 
places, is not observed in the Mardin Museum. This condition establishes an egalitarian urban place through providing free participation for individuals from all segments of the society to museum activities, without class segregation.

The activities conducted in the children's workshops in the museum attract the attention of both city children and families. These activities, which ensure the conveyance of non-concrete cultural heritage elements and cultural diversity to new generations, also ensure the establishment of a common social memory. Educational activities conducted via the workshops, which are an entertaining way of maintaining cultural identity, have transformed the museum into a place to learn by having fun; in other words, a place of edutainment. As a result, it can be said that the new spatialities formed by this edutainmenet place, where entertainment and education spatially intersect, have an effect on the spatial establishment of other museums.

\section{Kaynakça / References}

Abacı, O. (1996). Müze eğitimi. Yayımlanmamış sanatta yeterlilik tezi, Marmara Üniversitesi, İstanbul.

Addis, M. (2005). New technologies and cultural consumption: Edutainment is born!. European Journal of Marketing, 39(7-8), 729-736.

Aksakal, N. (2015). Theoretical view to the approach of the edutainment. Procedia - Social and Behavioral Sciences, 186, $1232-1239$.

Aktaş Arnas, Y. (2017). Oyun, öğrenme ve deneyimin birleşimi: çocuk müzeleri. Yaratıı Drama Dergisi, 12(2), 17-30.

Altunbaş, A. ve Özdemir, Ç. (2012). Çağdaş müzecilik anlayışı ve ülkemizde müzeler. http://teftis.kulturturizm.gov.tr/Eklenti/4655,makale.pdf adresinden 4.03.2019 tarihinde erişildi.

Anikina, O. V., ve Yakimenko, E. V. (2015). Edutainment as a modern technology of education. Procedia- Social and Behavioral Sciences, 166. 475-479.

Artar, M. (2010). Müzedeöğrenme. (Yay. Haz. B. Onur) Müze Eğitimi Seminerleri2: Mardin Müzeleri içinde, (s. 55-72). ÇOKAUM ve Mardin Valiliği Mardin Arkeoloji Müzesi Müdürlügü:

Atagök, T. (2003). Müzecilikte yeni yaklaşımlar.(Yay. Haz. B. Onur) Müze Ë̆itimi Semineri 1: Akdeniz Bölgesi Müzeleri içinde (s. 25- 29). Antalya: Suna-İnan Kuraç Akdeniz Medeniyetleri Araştırma Enstitüsü.

Ateşçi, E., İslamoğlu, G. (2014). Bir "edutainment" uygulamass: KidzMondo örneği, 1. Uluslararası İletişim Bilimi ve Medya Araştırmalarn Kongresi, 2, 388-397. 
Balloffet, P., Courvoisier, F. H., ve Lagier, J. (2014). From museum to amusement park: the opportunities and risks of edutainment, International Journal Of Arts Management, 16(2), 4-18.

Beale, K. ve Villeneuve, P. (2011). Museums at play. Edinburgh: MuseumsEtc.

Cembalest, R. (2009). Reshaping the art museum. ARTnews, 108(6), 76-81.

Chmiliar, 1. (2010). Multiple-case designs. A. J. Mills, G. Eurepas \& E. Wiebe (Eds.), Encyclopedia of case study research içinde (s. 582-583). USA: SAGE Publications.

Clutterbuck, R. (2008). Müzeleri anlamak. (yay.haz: İ. San,), Eğitim ve müze seminerleri içinde, Ankara: Kök yay.

Çiftçi, A., Acer, D. (2015). Çocuklar için mimari tasarım ve kültürel miras eğitiminde müzelerin işlevi: Finlandiya Ulusal Müzesi örneği, İdealkent Kent Araştırmalan Dergisi, 17, 62-79.

Dilli, R. (2017). Öğretmenlerin müzelerin öğrenme ortamı olarak kullanımına ilişkin görüşleri. Milli Eğitim, 214, 303-316.

Erdoğan, N. (2017). Mardin Müzesi: Müze eğitimi ve etkinlikleri. Mardin: Mardin Müze Müdürlüğü.

Feenstra, F., Muzellec, L., Faultrier, B., ve Boulay, J. (2015). Edutainment experiences for children in retail stores, from a child's perspective. Journal of Retailing and Consumer Services 26, 47-56.

Freedman, G. (2000). The changing nature of museums. Curator: The Museum Journal, 43(4), 295-306.

Gürhan, N. (2018). Simüle edilen toplumsal mekân/kentsel mekân: çocuk şehri temalı eğlence merkezleri, İdealkent Kent Araştırmalan Dergisi, 24, 701-732.

ICOM. (t.y). Museum. http://icom.museum/en/activities/standards-guidelines/museumdefinition/ adresinden 4.03.2019 tarihinde erişildi.

Ironico, S. (2012). The active rol of children as consumers. Young Consumers, 13(1), 30-44.

Karadeniz Akdoğan, K., Durmaz, E., Kimzan, L., ve Acer, D. (2019). Bir öğrenme ortamı olarak müze atölyeleri, Ankara Araştırmalan Dergisi, (2), 399-413.

Karadeniz, C., Okvuran, A., Artar, M. ve Çakır-İhan, A. (2015). Yeni müzebilim bağlamında müze eğitimine çağdaş yaklaşımlar ve müze eğitimcisi. Ankara Üniversitesi Eğitim Bilimleri Fakuiltesi Dergisi, 48(2), 203-226.

Kısa, Y. (2012). Sosyal bilgiler öğretiminde müze kullantmma ilişkin öğretmen ve öğrenci görüşlerinin incelenmesi Afyonkarahisar müzeleri. Yayımlanmamış yüksek lisans tezi. Afyon Kocatepe Üniversitesi, Afyonkarahisar.

Lepouras, G., ve Vassilakis, C. (2004). Virtual museums for all: employing game technology for edutainment. Virtual Reality, 8(2), 96-106. 
Mardin Müzesi. (t.y). Arkeopark. http://www.mardinmuzesi.gov.tr/tr/me-916-arkeopark adresinden 10.03.2019 tarihinde erişildi.

Mardin Müzesi. (t.y). Yaz okulu. http://www.mardinmuzesi.gov.tr/tr/me-915-yaz-okulu adresinden 5.03.2019 tarihinde erişildi.

Mercin, L. (2003). Kuiltür ve sanat degerlerinin yas,atlmasında müzelerin rolü. Elektronik Sosyal Bilimler Dergisi. 2(6), 106-114.

Mercin, L., ve Alakuş, A.O. (2005). Anadolu güzel sanatlar lisesi programlarının "müze eğitimi ve uygulamaları" dersi açısından değerlendirilmesi. Sanat Dergisi, 8, 110.

Meydan, A., ve Akkuş, A. (2014). Sosyal bilgiler öğretiminde müze gezilerinin tarihi ve kültürel değerlerin kazandırılmasındaki önemi. Marmara Coğrafya Dergisi, 29, $402-422$.

Millie, R.C. (1994). “Edutaining” children: Consumer and gender socialization in Japanese marketing, Ethnology, 33(1), 35-52.

Moffat, $\mathrm{H}$., ve Woollard, V. (2004). Museum and gallery education: a manuel of good practice, Lanham: Altamira Press.

Okan, Z. (2003). Edutainment: is learning at risk?. British Journal of Educational Technology, $255-264$.

Ölçer, E. (2004). “Söz" artık müzede: kültürel bellek, küreselleşme ve eğitim bağlamında sözlü kültürün korunması ve duyarlllk geliştirilmesi üzerine. Somut Olmayan Kültürel Mirasm Müzelenmesi Sempozyum Bildirileri. (s.84-90) .Ankara: THBMER Yay.

Öner, G. (2015). Sosyal bilgiler öğretmenlerinin okul dışı tarih öğretimine ilişkin görüşlerinin incelenmesi. Tü̈k Tarih Eğitimi Dergisi, 4(1), 89-121.

Öner, G., Uyar, F. O., ve Öner, D. (2019). Müzelerin eğitimsel işlevine ve kullanımna ilişkin müze uzmanlarının görüşleri. Kastamonu Education Journal, 27(6), 24392457.

Özer, M., ve Ylldırmm-Polat, A. (2019). Parents' views on education with the museum in the preschool period. Journal of International Museum Education, 1(1), 1-17.

Poris, M. (2006). Understanding what fun means to today's kids. Young Consumers, 7(1), $14-22$.

Rius-Ulldemolins, J. (2016). The rise of the hybrid model of art museums and cultural institutions: The case of Barcelona. Museum Management and Curatorship, 31(2), 178-192.

Schuster, J. M. (1998). Neither public nor private: the hybridization of museums. Journal of Cultural Economics, 22(2-3) 127-150. 
Sorathia, K., ve Servidio, R. (2012). Learning and experience: teaching tangible interaction \& edutainment. Procedia - Social and Behavioral Sciences 64 , 265- 274.

Subaşı, M., ve Okumuş, K. (2017). Bir araştırma yöntemi olarak durum çalışması. Atatürk Üniversitesi Sosyal Bilimler Enstitüsü Dergisi, 21(2), 419-426.

Şar, E., Sağkol, T. (2013). Eğitim fakültelerinde müze eğitimi dersi gerekliliği üzerine, Hasan Ali Yücel Ĕ̆itim Fakültesi Dergisi, 20, 83-90.

Tekin, G. (2017). Dönüşen müzecilik ve müzede öğrenme: Ankara Somut Olmayan Kültürel Miras Müzesi. Milli Eğitim, 214, 155-166.

Tezcan Akmehmet, K., Ödekan, A. (2006). Müze eğitiminin tarihsel gelişimi. İTÜ Sosyal Bilimler Dergisi, 3(1), 47-58.

Turanl, S. (2012). Oyuna dayalı müze etkinliklerinin öğrenci erişi ve görsel sanatlar dersine karşı tutumlan üzerine etkisi. Yayımlanmamış doktora tezi, Gazi Üniversitesi., Ankara.

Yalçınkaya, Ş. (2015). Modern kentin yeni kamusal alanında çocuk, alışveriş merkezleri ve serbest zaman etkinlikleri. İdealkent Kent Araştırmalan Dergisi, 17, 80-105.

Yıldırım A., ve Şimşek, H. (2013). Sosyal bilimlerde nitel araştırma yöntemleri. Ankara: Seçkin Yay.

Yılmaz, K. ve Şeker, M. (2011). İlköğretim öğrencilerinin müze gezilerine ve müzeleri sosyal bilgiler öğretimindekullanılmasınailişkin görüşlerinincelenmesi. İstanbul Aydın Üniversitesi Dergisi, 3(9), 21-39.

Yum, M. S. (2020). Eğitlence kavramı ve bu kavramın müze ve merkezlerdeki eğitim ekseninde kullanı deneyimi ile etkileşim odakl disiplinler arası tasarm kriterleri. Yayımlanmamış doktora tezi, Mimar Sinan Güzel Sanatlar Üniversitesi, İstanbul.

Zaidi, S. A. J. (2016). Gamification as a strategy to improve user-experience with interactive museum exhibits. Yayımlanmamış yüksek lisans tezi, Orta Doğu Teknik Üniversitesi, Ankara.

\section{Kaynakça Bilgisi / Citation Information}

Gürhan, N. (2021). Bir müzenin dönüşümü: Öğrence mekânı olarak Mardin Müzesi. OPUS-Uluslararası Toplum Araştırmaları Dergisi, 17(33), 565-594. DOI: 10.26466/opus.816832 